\title{
Mapping seismic exposure of building based surface peak ground acceleration: initial seismic risk assessment in Bandung Basin, West Java
}

\author{
Afnindar Fakhrurrozi ${ }^{1 *}$, Anggun Mayang Sari ${ }^{1,5}$, Arifan Jaya Syahbana ${ }^{1,2}$, Dwi Sarah ${ }^{1}$, Bambang Setiadi ${ }^{1}$, Mudrik \\ Rahmawan Daryono ${ }^{1}$, Rabieahtul Abu Bakar ${ }^{3}$, and Jian Cheng Lee ${ }^{4,5}$ \\ ${ }^{1}$ Research Center for Geotechnology (P2G-LIPI), Indonesian Institute of Sciences, Bandung, Indonesia \\ ${ }^{2}$ Faculty of Civil and Environmental Engineering, Bandung Institute of Technology, Bandung, Indonesia \\ ${ }^{3}$ Razak Faculty of Technology and Informatics, University Technology Malaysia (UTM), Kuala Lumpur, Malaysia \\ ${ }^{4}$ Institute of Earth Science, Academia Sinica, Taipei, Taiwan \\ ${ }^{5}$ Integrated Research on Disaster Risk-International Centers of Excellence (IRDR-ICoE), Taipei, Taiwan
}

\begin{abstract}
An important key to determining the disaster risk is exposure. It is truly dynamic in space and time due to the expansion and change of the settlements. A seismic hazard is an earthquake disaster that can deliver damage to the physical environment. Hence, it is required to analyse the objects exposed by an active earthquake source in the Bandung Basin. The exposed objects that experience the most impact due to the shock of the earthquake are residential buildings. The West Bandung Regency was opted as our study area due to the high-risk zone for earthquake waves based on seismic hazard calculation. This paper tried to analyse the seismic exposure as the impact of earthquake waves around the Bandung Basin on physical buildings in the West Bandung Regency using a geospatial analytics approach. The result shows that the location area with many damaged buildings correlates with the spatial distribution of surface peak ground acceleration.
\end{abstract}

\section{Introduction}

During the past two decades, the number of earthquakes has increased dramatically in West Java, primarily attributed to induced seismicity from the Sunda Megathrust and the Lembang Fault, as shown in Fig. 1 $[1,2,3]$. The increased seismic disaster risk has affected several West Java regencies, including West Bandung Regency. Thus, scientific information related to physical buildings that are affected by seismic hazards is needed.

Peak Ground Acceleration (PGA) computation can be used to determine the seismic hazard that affects buildings[4,5]. The PGA values on the surface were obtained using Earthquake waves propagation. These values were used as an input for spatial analysis.

Spatial analysis is to map the buildings that are exposed to seismic hazards. The spatial distribution of seismic hazards and buildings that are affected by seismic waves can be achieved with a geographic information system approach [6]. Spatial analysis to estimate the spatial distribution of point samples at the unknown location required interpolation. Two spatial interpolation methods are widely used by GIS practitioners, namely Inverse Distance Weighting (IDW) and Kriging [7]. The IDW interpolation method is claimed to have a lighter performance than Kriging [7]. Hence, this study applied

\footnotetext{
*Corresponding author: afnindar.fakhrurrozi@lipi.go.id
}

the IDW to map the seismic exposure of physical buildings.

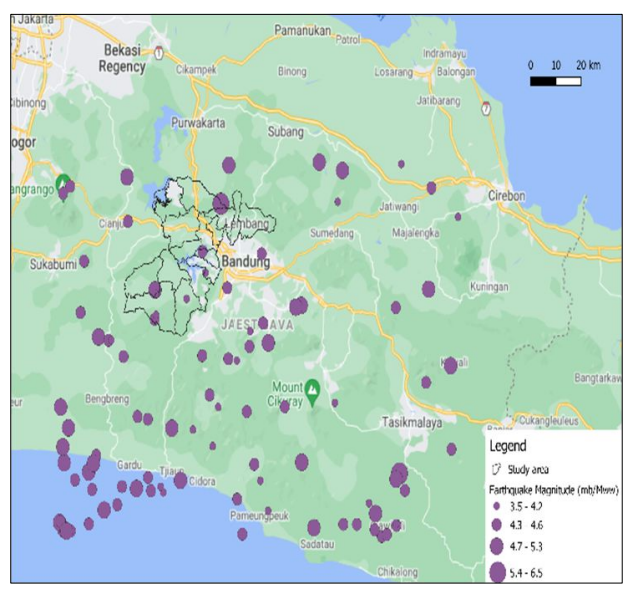

Fig. 1. Earthquake events in the last 20 years in West Java province. $\mathrm{Mw}>3.5$ (USGS)

\section{Study Area}

There are three sub-districts in West Bandung Regency; namely Batujajar, Cihampelas, and Cililin. Several soil field investigations, Core Penetrant Test (CPT), known as CPTu, settled on these areas, as shown in Fig. 2. 


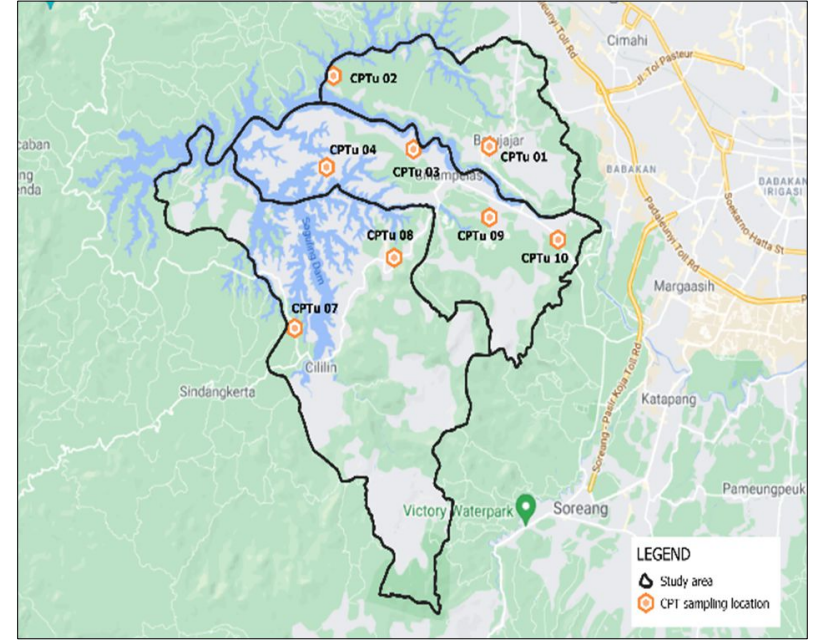

Fig. 2. The study area, along with the sampling location of CPT, is marked with an orange circle. It is consists of three sub-districts in West Bandung Regency.

CPTu-01 and CPTu-02 are located in the Batujajar sub-district. This area is a densely populated residential zone. Different from Batujajar area, Cihampelas subdistrict dominated by a water area, which is Saguling dam. The physical building is located in the eastern part of this subdistrict. CPTu-03, CPTu-04, CPTu-09 and CPTu-10 were found in this subdistrict. The third is Cililin subdistrict, which is the largest subdistrict in West Bandung Regency. This area consists of half land and half water, and the building infrastructures are distributed in the southern part of Cililin sub-district.

\section{Methodology}

The study used PGA values as the main source to map buildings that were exposed to seismic hazards. Nonlinear approach analysis was used to calculate the PGA values [8][9]. It was assumed that the shear waves had been propagated vertically in the one-dimensional layer under some soil layer conditions; homogenous, infinite extent, and horizontal motion [10]. It can be expressed in a given equation:

$$
\rho \frac{\partial^{2} d}{\partial t^{2}}+\eta \frac{\partial d}{\partial t}=\frac{\partial \tau}{\partial z}
$$

Where $\rho$ is the soil unit mass, $\mathrm{d}$ is horizontal displacement, $\mathrm{z}$ is the depth, $\mathrm{t}$ is the time, $\tau$ is the shear stress, and $\eta$ is the mass damping parameter. The displacement, velocity, and acceleration are then calculated using a finite difference formulation as follows:

$$
\begin{gathered}
\frac{\partial \tau}{\partial z}=\frac{\left(\tau_{i}+1\right)-\left(\tau_{i}-1\right)}{\Delta z} \\
a_{i, n}=\frac{\partial^{2} d}{\partial t^{2}}=\frac{\bar{v}_{i, n+\Delta n}-\bar{v}_{i, n}}{\Delta t}
\end{gathered}
$$

Where $\bar{v}$ is motion velocity, $a_{i, n}$ is the acceleration at nodes $\mathrm{i}(\mathrm{i}=1, \ldots, \mathrm{n})$ and $\mathrm{n}$-step. The PGA computation was applied to eight CPT samples. The location of each CPT sample can be seen in Fig. 2.

The PGA values were interpolated using IDW to estimate the PGA distribution. The IDW calculates the weighted averages of sample values to estimate the unknown value $\hat{z}$ given particular location $\mathrm{x}[7,11]$. Mathematically, the IDW method can be represented as:

$$
\begin{gathered}
\hat{z}(x)=\frac{\sum_{i}^{n} w_{i} z_{i}}{\sum_{i}^{n} w_{i}} \\
w_{i}=\left|x-x_{i}\right|^{-\beta}
\end{gathered}
$$

Where $\beta$ is the inverse distance power and $\beta \geq 0, w_{i}$ is the weight value at $n(n=1, \ldots, n)$ location that is the euclidean distance, and $\mathrm{z}$ is the observed value.

A field survey was carried out to obtain ground truth data of physical building using the Global Earthquake Model (GEM) taxonomy framework. Moreover, stratified random sampling was employed to select sample sites. There are ten random samples placed inside a rounded buffer of $2.5 \mathrm{~km}$ of each CPT sample. There are 80 random physical building sample data over $8 \mathrm{CPT}$ points that were collected.

The parcel of building map was developed by using manual digitization due to data limitations.

\section{Results}

The PGA values on each sample location vary between $0.47-0.70$, as shown in Table 1 .

Table 1. The PGA computation result

\begin{tabular}{|c|c|}
\hline ID & $\boldsymbol{a}_{\text {max }}$ surface \\
\hline CPTu-01 & 0.54 \\
\hline CPTu-02 & 0.62 \\
\hline CPTu-03 & 0.54 \\
\hline CPTu-04 & 0.70 \\
\hline CPTu-07 & 0.52 \\
\hline CPTu-08 & 0.47 \\
\hline CPTu-09 & \\
\hline CPTu-10 & 0.51 \\
\hline
\end{tabular}




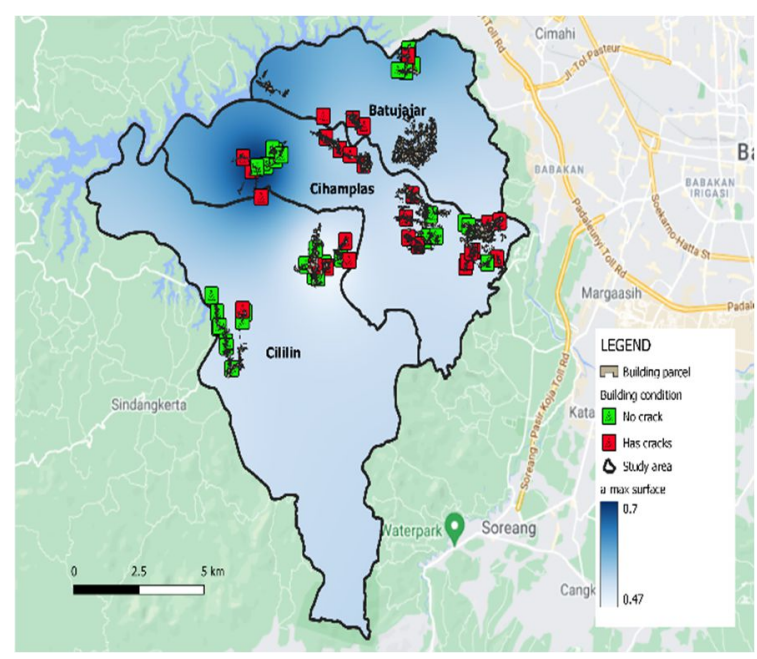

Fig. 3. The interpolated map of PGA values on the surface along with the building parcel and the building condition.

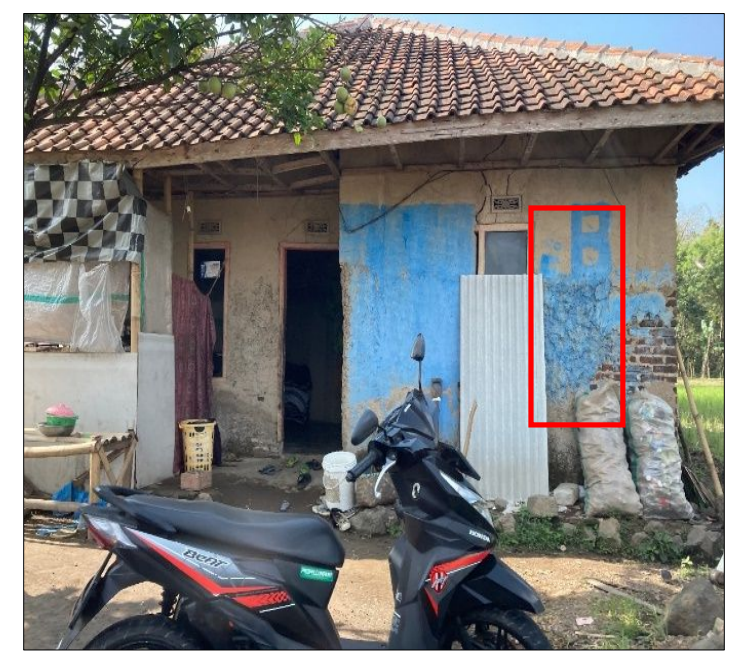

Fig. 4. A building located at CPTu-04. It has a wide crack opened and was marked inside a red box.

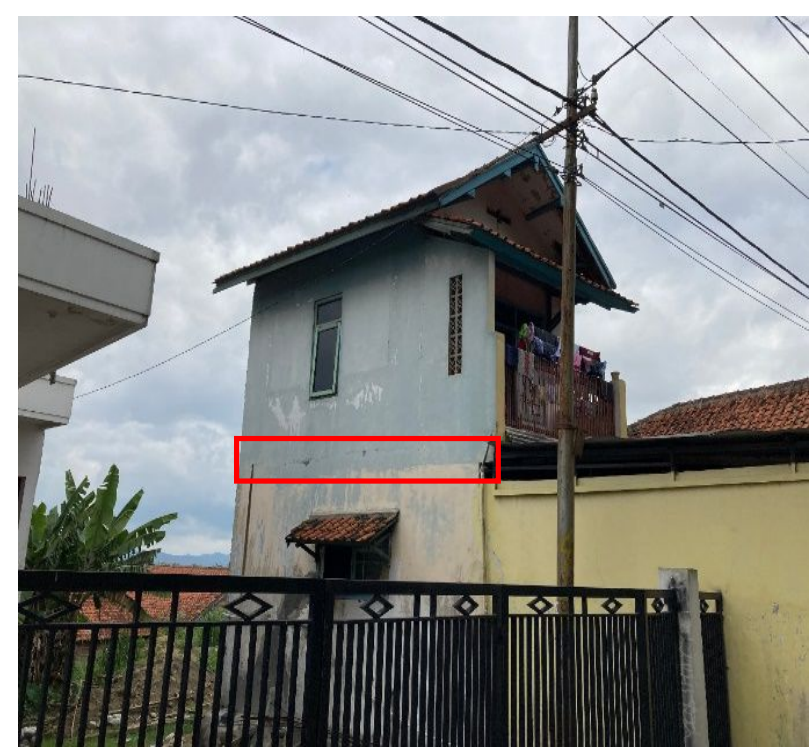

Fig. 5. A building located at $\mathrm{CPTu}-08$ has structural damage. It was marked inside a red box.

Building condition in CPTu-04 located at Cihamplas that has been severely damaged can be seen in Fig. 4. On the one hand, the building with cracks in the Cililin subdistrict can be seen in Fig. 5.

The highest value of PGA is located at Cihamplas subdistrict, while the lowest value is located at Cililin subdistrict. There is a strong correlation between the PGA value on the surface and the building that has cracks. It can be seen in Fig. 3. There are many buildings in Cihamplas sub-district that have cracks. The number of damaged buildings observed in Cihamplas is almost 70\%. Conversely, Cililin sub-district that has the lowest value of PGA also has lesser damaged buildings, with approximately $25 \%$ of total buildings having cracks.

\section{Conclusion}

The seismic exposure of building maps gives us insight into the particular area prone to an earthquake disaster. It also can help to predict and estimate the building damages and losses. Our result confirms that the PGA value on the surface has a strong correlation with the number of damaged buildings. This shows that using the geospatial analytics approach can capture the seismic exposure related to the existing buildings. However, in future research, we must delve deeper into the causes of structural damage using building taxonomies classification and machine learning to automate building footprint extraction using high-resolution imageries and estimate the number of damaged buildings. Hence, we can model and quantify the number of building exposed to seismic hazards more precisely.

The authors would like to extend our appreciation to the Research Center for Geotechnology, the Indonesian Institute of Sciences, for their full support during the research. This research is funded by the Advanced Institute Seed Grant Program of the International Science Council Regional Office for Asia and the Pacific (ISC ROAP) and Integrated Research on Disaster Risk and the International Centre of Excellence Taipei (IRDR ICoETaipei). This research also is supported by Innovation System Research project funding (INSINAS 2021).

\section{References}

1. I. W. Sengara, Y. Munaf, and I. Susila, Int. Conf. Recent Adv. Geotech. Earthq. Eng. Soil Dyn. 1 (2001)

2. M. R. Daryono, D. H. Natawidjaja, B. Sapiie, and P. Cummins, Tectonophysics 751, 180 (2019)

3. A. J. Syahbana, A. M. Sari, E. Soebowo, M. Irsyam, M. Asrurifak, and Hendriyawan, Proc. 20th Southeast Asian Geotech. Conf. 3rd AGSSEA Conf. Conjunction with 22th HATTI Annu. Sci. Meet. Thema Geotech. Chall. Mega Infrastructures (Indonesian Society for Geotechnical Engineering, Jakarta), 290-295 (2018)

4. A. Sari, A. Fakhrurrozi, and A. Syahbana, Proc. Proc. 7th Math. Sci. Comput. Sci. Educ. Int. Semin. MSCEIS 2019, 12 Oct. 2019, Bandung, West Java, Indones. (EAI, 2020) 
5. A. M. Sari, E. Soebowo, A. Fakhrurrozi, A. J. Syahbana, and A. Tohari, Ris. Geol. Dan Pertamb. 29, 53 (2019)

6. S. Derakhshan, M. E. Hodgson, and S. L. Cutter, Appl. Geogr. 124, 102295 (2020)

7. A. Barbulescu, A. Bautu, and E. Bautu, Appl. Sci. 10, (2020)
8. S. Kramer, Geotechnical Earthquake Engineering (Prentice-Hall, New Jersey, 1996)

9. H. Arslan and B. Siyahi, Environ. Geol. 50, 1193 (2006)

10. J. Bardet and T. Tobita, (2016)

11. B. Hartmann, K., Krois, J., Waske, (2018) 